Only in somes cases is the nutritional value of a feed determined by digestibility trials with experimental animals.

It has now been proved that Kellner's Starch Equivalent system is not accurate. However, although most of its weaknesses are now apparent, it is still considered the best method of estimating the nutritional value of feeds in Greece since the new systems (RosTOCK, VAN Es, ARC) are not yet widely known.

\title{
Irish Republic energy and protein feeding standards for growing and fattening cattle
}

\author{
T.W. GRIFFITHS \\ The Agricultural Institute, Dunsinea, Castleknock, \\ Co. Dublin, Ireland.
}

\section{Introduction}

There are no officially adopted feeding standards in the Irish Republic but both the Scandinavian Feed Unit and the British Starch Equivalent system have been used. However, when the new system of energy feeding standards (MAFF, 1975) based on metabolisable energy (ME) was adopted in Britain it was not officially adopted in Ireland although the system is being used on a limited scale. A joint committee representing agricultural and veterinary research and education has recommended a system of energy feeding standards similar to, but not identical with, that used in the UK. The proposed system is described in this paper.

\section{A. Energy feeding standards for growth}

The system is based on the expression of both the nutritive value of feeds and the nutritive requirements of animals in terms of $\mathrm{ME}$, and uses the megajoule (MJ) as the basic unit of energy. Requirements for ME are obtained from the calculated net energy (NE) requirement for maintenance and growth and the partial efficiency $(k)$ with which dietary $\mathrm{ME}$ is used to satisfy these requirements.

\section{Energy requirements for maintenance}

Minimum requirement for maintenance - fasting metabolism (FM) is considered to be the $\mathrm{NE}$ requirement for maintenance and is related to liveweight (W). Efficiency of utilisation of ME for maintenance $\left(k_{m}\right)$ is related to the metabolisability of the diet $(\mathrm{Q})$ :

$$
k_{m}=0.287 \mathrm{Q}+0.55
$$

However, for the range of $\mathrm{Q}$ values which are normally found in Ireland $k_{m}$ lies between 0.68 and 0.76 and a mean value of 0.72 has been taken. The value for $F M$ of $360 \mathrm{~kJ} \mathrm{ME} / \mathrm{kg} \mathrm{W}^{0.75}$ has been adopted. An additional allowance for activity (A), mainly locomotion, of 5 per cent has also been included. Metabolisable energy requirements for maintenance $\left(\mathrm{ME}_{m}\right)$ are therefore given by:

$$
\mathrm{ME}_{m}=\frac{\mathrm{FM}}{0.72}+\mathrm{A}=525 \mathrm{~kJ} / \mathrm{kg} \mathrm{W^{0.75 }}
$$

(Estimates of maintenance requirements made by regression analysis of ME intake on energy and nitrogen retention in housed Friesian cattle have given values of around $480 \mathrm{~kJ} \mathrm{ME} / \mathrm{kg} \mathrm{W}^{0.75}$ ). 


\section{Energy requirements for growth and fattening}

The ME requirement for body gain is taken as the product of the NE value of the gain in weight and the efficiency with which dietary ME is used for the deposition of body energy. It was considered that the best available data on the energy value of body weight gain $\left(\mathrm{NE}_{g}\right)$ were that of LoFGREEN and GARRETT (1968). Summarised data on the composition of body gain are: for steers $\underset{(\mathrm{MJ})}{\mathrm{NE}}=\left(0.221 g+0.029 g^{2}\right) \mathrm{W}^{0.75}$

where $g$ is empty bodyweight gain $(\mathrm{kg})$.

TABLE 1

RECOMMENDED ME ALEOWANCES FOR GROWING STEERS (MJ/daY)

\begin{tabular}{|c|c|c|c|c|c|c|}
\hline \multirow{2}{*}{$I W$} & \multirow{2}{*}{$M / D$} & \multirow{2}{*}{ Maintenance } & \multicolumn{4}{|c|}{ Liveweight gain } \\
\hline & & & 0.25 & 0.5 & 0.75 & 1.0 \\
\hline \multirow{3}{*}{200} & 8 & & 36 & 43 & - & - \\
\hline & 10 & 28 & 35 & 41 & 48 & 55 \\
\hline & 12 & & 34 & 39 & 45 & 50 \\
\hline \multirow{3}{*}{250} & 8 & & 43 & 52 & - & - \\
\hline & 10 & 33 & 40 & 48 & 56 & 64 \\
\hline & 12 & & 41 & 46 & 53 & 59 \\
\hline \multirow{3}{*}{300} & 8 & & 49 & 60 & - & - \\
\hline & 10 & 38 & 46 & 55 & 64 & 73 \\
\hline & 12 & & 45 & 52 & 61 & 69 \\
\hline \multirow{3}{*}{350} & 8 & & 55 & 67 & - & - \\
\hline & 10 & 43 & 52 & 62 & 73 & 83 \\
\hline & 12 & & 51 & 59 & 70 & 80 \\
\hline \multirow{3}{*}{400} & 8 & & 60 & 73 & - & - \\
\hline & 10 & 47 & 58 & 68 & 80 & 92 \\
\hline & 12 & & 56 & 65 & 75 & 85 \\
\hline \multirow{3}{*}{450} & 8 & & 65 & 80 & - & - \\
\hline & 10 & 51 & 63 & 74 & 87 & 100 \\
\hline & 12 & & 61 & 71 & 82 & 93 \\
\hline \multirow{3}{*}{500} & 8 & & 72 & 88 & - & - \\
\hline & 10 & 56 & 69 & 81 & 95 & - \\
\hline & 12 & & 67 & 77 & 89 & 100 \\
\hline
\end{tabular}


The relationship between the efficiency of utilisation of ME for body energy gain $\left(k_{g}\right)$ and the metabolisability of the diet $(\mathrm{Q})$ has been taken as:

$$
k_{g}=0.78 \mathrm{Q}+0.006
$$

Total requirements are represented by:

$$
\mathrm{ME}_{m+p}=\mathrm{ME}_{m}+\frac{\mathrm{NE}_{g}}{k_{g}}
$$

Table 1 gives the ME requirements for steers of different liveweights and gaining at various rates. The $Q$ value of the diets has been expressed in terms of $M / D$ (ME/DM). An arbitrary increase of 10 per cent in these values is suggested for heifers and a decrease of 10 per cent for bulls.

\section{Estimation of the ME values of feeds $(M J / \mathrm{kg} D M)$}

The ME value of concentrates is generally taken from published data (MAFF, 1975 ; RowETT INSTITUTE, 1975, 1978). For roughages and, in particular, grass silages (which are widely used in Ireland) estimation of $\mathrm{ME}$ is based on measurement of in vitro DM digestibility values (IVDMD). These are converted to in vivo DOMD values and hence to ME using the relationship ME $=0.15$ DOMD. The equation suggested for the estimation of the ME of grass silages is :

$$
\underset{(\mathrm{MJ})}{\mathrm{ME}}=\underset{\text { per cent }}{0.12}+1.7
$$

\section{B. Requirements for protein by growing animals}

Again, there are no officially adopted standards for protein requirements in Ireland. Whilst digestible crude protein (DCP) is used it is more normal to refer simply to the crude protein (CP) content of the diet. Metabolic work has consistently shown high correlations between DCP and CP (GRIFFITHS, 1977, 1978).

The following standards are tentative and have been derived from metabolic and comparative slaughter experiments (GRIFFITHS, 1977, 1978). Table 2 gives estimated requirements in terms both of DCP and CP for rates of gains of up to $1 \mathrm{~kg}$ per day in cattle between 150 and $450 \mathrm{~kg}$ liveweight.

TABLE 2

REQUIREMENTS FOR PROTEIN BY GROWING CATTLE ( $\mathrm{kg} /$ daY)

\begin{tabular}{lccccccccc}
\hline & & & & \multicolumn{7}{c}{ Liveweight } & $(\mathrm{kg})$ \\
& & 150 & 200 & 250 & 300 & 350 & 400 & 450 \\
\hline \multirow{2}{*}{ Maintenance } & DCP & 0.12 & 0.13 & 0.14 & 0.15 & 0.16 & 0.17 & 0.18 \\
& $C P$ & 0.31 & 0.33 & 0.34 & 0.35 & 0.37 & 0.38 & 0.39 \\
\hline $0.5 \mathrm{~kg} / \mathrm{d}$ LWG & DCP & 0.25 & 0.26 & 0.27 & 0.29 & 0.32 & 0.35 & 0.37 \\
& $C P$ & 0.49 & 0.50 & 0.52 & 0.54 & 0.58 & 0.62 & 0.64 \\
$1.0 \mathrm{~kg} / \mathrm{d}$ LWG & DCP & 0.38 & 0.40 & 0.43 & 0.45 & 0.48 & 0.50 & 0.52 \\
& $C P$ & 0.66 & 0.69 & 0.73 & 0.76 & 0.80 & 0.83 & 0.85 \\
\hline
\end{tabular}

DCP Digestible crude protein

CP Crude protein 
In practical terms these standards require levels of $\mathrm{CP}$ in diets for cattle growing at $1 \mathrm{~kg} /$ day to be around 15 per cent of the DM at $150 \mathrm{~kg} \mathrm{LW}$ falling to around 10 per cent at $400 \mathrm{~kg}$ and above. For feeding systems based on grass and grass silage these levels are almost always exceeded.

\title{
References
}

Blaxter K.L., 1974. In Nutr. Conf. Feed Manuf., Nottingham, 7, 3. Butterworths, London.

GRIFFITHS T.W., $1977 . \quad$ Ir. J. agric. Res. 16, 11.

Griffiths T.W., 1978. Anim. Prod. 26, 233.

Lofgreen G.P., Garrett W.N., 1968. J. Anim. Sci. 27, 793.

Ministry of AGRICUlTuRE, Fisheries AND FoOd, 1975. Energy allowances and feeding systems for ruminants. Tech. Bull. 33, HMSO, London.

ROWETT ReSEARCh InstitUTe, 1975. Feedingstuffs Evaluation Unit, First Report.

RowetT Research Institute, 1978. Feedingstuffs Evaluation Unit, Second Report.

VAN Es A.J.H., 1975. Livestock Prod. Sci. 2, 95.

\section{Netherlands energy and protein feeding standards for growing and fattening cattle}

\author{
A.J.H. VAN ES \\ Research Institute for Livestock Feeding and Nutrition, \\ Lelystad, The Netherlands
}

\section{Energy}

In 1977 the system of feed evaluation based on Starch Equivalent was replaced by two new systems, one for dairy cows including young animals for the dairy herd, and one for other growing cattle. Detailed information on the new systems has been published (VAN Es, 1978) ; in this contribution only the major elements will be dealt with.

In both systems (Table 1) firstly the content of ME of the feedstuffs was calculated from measured or predicted contents of digestible nutrients (DO or DXP, DXL, DXF and DXX).

Next, for growing cattle, the approach of HARKINs et al. (1974) was followed, in which different efficiencies $k_{m}$ and $k_{f}$ are used for the maintenance and production parts of metabolism. Both $k$-values were related to $q$ : for $k_{m}$, based on our own work and the literature; for $k_{f}$, after BLAXTER (1974):

$$
k_{m}=0.554+0.00287 q \text { and } k_{f}=0.0078 q+0.006
$$

A value of $110 \mathrm{kcal} M E$ per $\mathrm{W}_{4}$ was used as the maintenance requirement of growing cattle kept loose and in groups at the farm. Daily energy gain RE was computed from body weight and daily liveweight gain using the equation given in Table 1, derived from various studies (VAN Es, 1978). Together this information allowed the animal production level (APL) of an animal to be calculated at a given liveweight and daily gain, and thus also the efficiency of the utilisation of the ME for maintenance and gain $k_{m}, f$. Multiplication of ME by $k_{m, f}$ gave the net energy content of a ration for growth. Its prediction equation still contained APL, so the net energy content of the same ration would vary with the rate of gain. In most cases the APL of growing cattle is close to 1.5 , so it was decided (as in the case of France and Switzerland) to use only one APL value equal to 1.5 to calculate the net energy contents of feedstuffs. Any errors made at lower or higher rates of gain than the $0.9 \mathrm{~kg} / \mathrm{d}$ applying to an APL of 1.5 were largely compensated for by slight changes in the 